\title{
Sometimes Close is Good Enough: The Value of Nearby Environmental Amenities ${ }^{\otimes}$
}

\author{
Lucie Schmidt \\ Department of Economics \\ Williams College \\ Paul N. Courant \\ Department of Economics and \\ Gerald R. Ford School of Public Policy \\ University of Michigan
}

September 2003

\footnotetext{
${ }^{\otimes}$ We are grateful to Bonggeun Kim for initial data collection as well as extremely helpful comments, and to Seiwoon Hwang for research assistance. We would also like to thank Emma Hutchinson, Matthew Kotchen, Purvi Sevak, Stephen Sheppard, Lara Shore-Sheppard, and participants in the University of Michigan Public Finance Seminar for useful suggestions. All errors and omissions are our own.

Corresponding author: Lucie Schmidt, Department of Economics, Fernald House, Williams College, Williamstown, MA 01267; (413) 597-3143; Email: 1schmidt@williams.edu.
} 


\title{
Sometimes Close is Good Enough: The Value of Nearby Environmental Amenities
}

\begin{abstract}
An extensive empirical literature exists showing that variations in region-specific amenities can account for persistent differences in real wages acro ss regions. However, this literature has considered only amenities in the same location as the household. This paper argues that environmental amenities at some distance from but accessible to urban areas may lead to negative compensating wage differentials. We use a general equilibrium framework and data from the 1995 Current Population Survey to calculate implicit amenity prices based on measures of distance to environmental amenities. Our results suggest that amenities outside the metropolitan area do generate compensating wage differentials, as workers are willing to accept lower wages to live in accessible proximity to "nice" places. This implies that these places provide a positive externality to those communities that find them accessible. The estimated effects are quantitatively important, suggesting that these externalities should be taken into account in policy making.
\end{abstract}




\section{$\underline{\text { Introduction }}$}

Rapid growth in the Pacific Northwest over the 1980s and 1990s has been difficult to explain in the context of traditional economic models of regional growth. The input-output framework used by many economic development organizations predicted that reductions in logging due to environmental policy would have permanent negative effects on the economies of the affected areas. Instead, the region experienced strong economic growth over this time period. It has been suggested that this economic growth might have resulted in part because of the protection of natural resources in the area, rather than in spite of it. ${ }^{1}$

This possibility is consistent with a fairly extensive empirical literature showing that variations in region-specific amenities can account for persistent differences in real wages across regions. ${ }^{2}$ The presence of an amenity valued by workers generates negative compensating wage differentials, as a higher supply of workers drives down wages in that area. At the same time, the presence of an amenity increases demand for housing in the region, which generates positive rent differentials. ${ }^{3}$ Such amenities can generate sizeable effects on wages. For example, Blomquist et al. (1988) rank 253 urban counties in 1980 based on the estimated value of their amenities, and find that the difference in amenities between the top-ranked and bottom ranked counties could be valued at over $\$ 5,000$ per household per year. This value exceeds 28 percent of the median household income in 1980, which was $\$ 17,710$.

\footnotetext{
${ }^{1}$ For example, see Courant et al. (1997), Lerner and Poole (1999), Niemi et al. (1999), Power (1996); and Rudzitis and Johnson (2000).

${ }^{2}$ See Gyourko et al. (1999) for a recent summary.

${ }^{3}$ These arguments are generally made for local natural resource amenities such as clean air or miles of coastline, but can also apply to publicly provided amenities including excellent school systems and low crime rates. See Smith and Huang (1995) and Gyourko and Tracy (1991).
} 
The empirical literature to date has considered only amenities that are in the same location (usually the county or the metropolitan statistical area) as the household. The argument tested here is that environmental amenities at some distance from but accessible to urban areas may have a value to consumers that can lead to negative compensating wage differentials. These wage differentials, in turn, serve as production amenities, attracting industrial and commercial activity and generating economic growth.

Note that this argument suggests that the travel cost approach to valuing amenities, first proposed by Hotelling in the 1930s, may be misspecified. The travel cost approach involves the surveying of visitors to outdoor recreation sites to find how much expenditure was incurred in order to get there. These travel costs become a proxy for the price of visiting recreation areas. Observed visits and the estimated costs are then used to trace out an implicit demand curve for the environmental amenity. ${ }^{4}$

If our argument is correct, residential location itself is not exogenous, and in fact is likely to be strongly influenced by the presence of natural amenities. For example, people who enjoy kayaking are likely to live near rivers where they can do so. Thus, residential location, which is the origin of the recreational travel, is chosen in part as a function of the amenities, causing the travel cost approach to systematically underestimate the value of natural amenities. ${ }^{5}$

In this paper, we assume that individuals choose their residential location based in part on proximity to "nice" places. We use a general equilibrium framework similar to that of Rosen (1977), Roback (1982, 1988), and Beeson (1991) to calculate implicit

\footnotetext{
${ }^{4}$ For an example see Bowes and Krutilla (1989). Fletcher et al. (1990) provide a review of this methodology.

${ }^{5}$ One can imagine writing down a richer model, in which residential locations are explicitly chosen simultaneously with recreational trips, but that is beyond the scope of the current analysis.
} 
amenity prices based on measures of distance to environmental amenities. Using data from the Census Bureau's 1995 Current Population Survey, we regress log weekly real earnings on individual attributes considered to influence wages, including race, marital status, age, education, experience, and union membership. We also include area-specific attributes of the metropolitan area in which the individual resides. Our paper extends the literature by also including measures of distance to "nice" places.

Our results suggest that natural resource amenities outside the metropolitan area do generate compensating wage differentials, as workers are willing to accept lower wages to live in accessible proximity to "nice" places. This implies that "nice" places provide a positive externality to those communities that find them accessible. It will therefore generally be very difficult to assure optimal provision of the amenity, either through market or nonmarket means. It is difficult enough to organize local jurisdictions to produce amenities efficiently within their own borders. Here the problem is much more complicated, as the relevant amenities will generally be produced in jurisdictions that are distinct from those in which the affected employers and employees transact their business. The effects that we estimate are quantitatively important, suggesting that these externalities should be taken into account in the making of environmental and natural resource policy. 


\section{Model}

Our theoretical approach draws heavily upon the work of Courant and Deardorff (1993) and Courant et al. (1997). We assume that the preferences of a consumer can be represented by the indirect utility function $V$ :

$$
V_{j}=V\left(R_{j}, w_{j}, G_{j}, \Gamma_{j}\right)
$$

where $j$ denotes the location of residence, $R_{j}$ is rent, $w_{j}$ is the wage, $G_{j}$ is consumption of governmentally provided goods and services, and $\Gamma_{j}$ represents a vector of environmental amenities within the consumer's region of residence.

Imagine a simple economy with two regions, A and B. In this case, locational equilibrium will require that

$$
V\left(R_{A}, w_{A}, G_{A}, \Gamma_{A}\right)=V\left(R_{B}, w_{B}, G_{B}, \Gamma_{B}\right)
$$

Specifically, if region B is amenity-rich relative to region $A$, so that $\Gamma_{B}>\Gamma_{A}$, then, holding the level of government services constant, equilibrium requires that

$$
\frac{w_{A}}{R_{A}}-\frac{w_{B}}{R_{B}}>0
$$

The real wage in region A must adjust upward to compensate for the environmental amenities present in region B. ${ }^{6,7}$

The term $\Gamma_{j}$ in equation (2) has generally been limited to include only those environmental amenities within the consumer's region of residence. As such, the typical

\footnotetext{
${ }^{6}$ The assumption of equilibrium in the regional markets for wages and rents, if inaccurate, could lead to biased estimates of amenity valuations. However, work by Greenwood et al. (1991) suggests that any biases due to the erroneous assumption of regional equilibrium appear to be both quantitatively and qualitatively minor.

${ }^{7}$ Equations (1-3), as written, implicitly assume that all consumers have identical tastes and ability to earn labor income. More generally, each equation will apply to consumers of a particular type. As long as consumers of a given type choose to locate in more than one region, compensating real wage differentials that take the form of equation (3) should be observed.
} 
regression in the empirical literature estimates the real wage as a function of a vector of attributes within a Metropolitan Statistical Area. However, $\Gamma_{j}$ could easily be specified to include a set of amenities at a distance from $j$ that depend on the location of $j$. The innovation of this paper is to add measures of accessibility to amenable places that are outside of the MSA. Specifically, we alter the model such that Equation (2) becomes:

$$
V\left(R_{A}, w_{A}, G_{A}, \Gamma_{A}, \Theta_{A}\right)=V\left(R_{B}, w_{B}, G_{B}, \Gamma_{B}, \Theta_{B}\right)
$$

where $\Theta_{j}$ is a measure of distance to "nice" places.

\section{Data, Model Specification and Empirical Results}

We use data from the Current Population Survey (CPS) March Supple ment for 1995 (corresponding to calendar year 1994). The CPS is a nationally representative monthly survey of households conducted by the Bureau of the Census for the Bureau of Labor Statistics, and is the primary source of information on the labor force characteristics of the U.S. population. The March supplement provides extensive demographic information on the individuals in the sample. Our sample consists of full time workers over the age of 18 , who resided in one of the 90 biggest metropolitan statistical areas (MSAs) within the contiguous United States, and includes 28,282 observations. A list of the MSAs used in the analysis can be found in Appendix A. The CPS individual-level data on income, job characteristics, and demographics were merged with characteristics of the metropolitan areas. Summary statistics are presented in Table 1. Details on the specific variables and how they were created can be found in Appendix B. 
The hypothesis that we wish to test is whether individuals are willing to accept lower wages to live in closer proximity to amenity-rich places. We therefore need to define a set of these amenity-rich, or "nice" places. In this paper, we define "nice" places as those including national parks, lakeshores, and seashores. A full list can be found in Appendix C. ${ }^{8}$

As a baseline, we first estimate the following model, which allows only those amenities within the MSA to generate compensating differentials:

$$
L N_{-} R W A G E_{i}=\alpha+\beta_{1} X_{i}+\beta_{2} \Gamma_{j}+\varepsilon_{i}
$$

where $i$ indexes the individual, and $j$ indexes the MSA. Our dependent variable, LN_RWAGE, is the natural log of the real wage of individual $i .^{9}$ Our real wage measure adjusts for regional cost-of-living differences using MSA-specific deflators. The $X_{i}$ vector includes individual level characteristics that affect wages, including age, sex, race, marital status, number of children, union membership, education, and veteran status. The $\Gamma_{j}$ vector contains MSA-level characteristics that have been shown to be associated with compensating wage differentials. These include natural amenities, such as climate, surface water area, topographical variation, state recreation acreage, and measures of air quality. ${ }^{10,11}$ Individuals are willing to accept lower wages in order to live in areas with

\footnotetext{
${ }^{8}$ Clearly, national parks, lakeshores, and seashores hardly constitute an exhaustive list of "nice" places. Following the usual logic of errors-in-variables, we believe that our estimates of the effect of proximity to these locations on real wages will be an underestimate of the true effect. See Wooldridge (2002).

${ }^{9}$ The theory of urban location is a theory about the real wage. As such, we use log real wages, adjusted for differences in the cost of living across MSAs, as our dependent variable. However, many of the previous papers in this literature estimate separate equations for wages and rents, and use coefficients from both regressions to generate implicit prices of amenities. Since rent differences comprise the majority of regional variation in cost of living, results from the two approaches should not differ substantively.

10 See Roback (1982) and Blomquist, et al. (1988).

${ }^{11}$ We do not include publicly created amenity variables such as school quality and law enforcement in our regression. Using these variables on government produced amenities would require inclusion of a full set of government revenue variables, which would be difficult to generate at the MSA level. Omission of the public sector will not affect coefficient estimates. It would significantly affect comprehensive quality of
} 
amenities, so the coefficients on amenities are expected to be negative. ${ }^{12}$ The error term is represented by $\varepsilon_{i}$. We calculate robust standard errors that are corrected for within MSA correlation. ${ }^{13}$

Results from this regression, estimated on a pooled sample of men and women, can be found in Column 1 of Table 2. The individual level variables generally have the expected sign and are statistically significant. Individuals who are male, white, married, and union members earn higher wages. Wages rise with age, but at a declining rate. In addition, there higher levels of education are significantly associated with higher wages. Natural amenities within the MSA have effects in the direction predicted by the theory. Surface water area, percent of MSA that is state recreation area, and topographical variation (amenities) have a negative effect on wages, and unhealthy air quality days and superfund sites per capita (disamenities) have a positive effect, although the point estimates are not statistically different from zero. One of the natural amenity variables does enter the regression significantly -- the average climate index. The estimated coefficient is -0.069 , and is statistically significant at the five-percent level.

life rankings (see

Gyourko and Tracy (1991)) but we do not generate those rankings in this paper.

${ }^{12}$ As Rosen (1979) points out, when there are unobserved differences in tastes for ame nities, the estimated wage differences will generally overstate the amount that residents in the high wage region would accept as a pay cut to move to the low-wage region, and understate the compensation increase that residents in the low-wage region would require to move to the high-wage region. One can imagine a world in which the equilibrium condition in equation (3) never holds, because heterogeneity in tastes, the specific distribution of types of people, and resulting geographic sorting, are such that people with identical tastes and endowments are never observed in different locations. In this case, the observed real wage differences generally understate the value of the amenity difference to any given consumer.

${ }^{13}$ Moulton (1986) shows that when the unit of observation is the individual but the independent variables of interest vary only across regions, uncorrected standard errors from Ordinary Least Squares (OLS) can be severely understated, leading to misleading interpretations of the significance of coefficients. We have also run the regressions with random effects specifications, and find coefficients on the variables of interest that are similar in magnitude and significance to those reported here. The Hausman test from the pooled regression suggests that this specification is valid, but the corresponding tests for the regressions run separately for men and women show that the data violate the assumption that the random effects are uncorrelated with the explanatory variables. Because of this, we do not report these random effects results 
The magnitude of this coefficient suggests that moving from the mean level of the climate index (a climate similar to that of Charlotte, NC) to a level one standard deviation worse (a climate similar to that of Cleveland, $\mathrm{OH}$ ) would require a $4.8 \%$ increase in wages to compensate the average individual and leave their utility unchanged.

Columns 2 and 3 of Table 2 present results broken out by gender. There is now a significant marriage premium for men, but not for women, consistent with much of the labor literature (see, for example, Ginther and Zavodny (2001), Gray (1997), and Korenman and Neumark (1992)). In addition, the presence of children under the age 18 is associated with a significant wage premium for men, and a significant wage penalty for women. Most of the MSA-level variables are still not statistically different from zero. Climate, which was significant at the five-percent level in the pooled sample, is statistically significant for men only, at the five-percent level.

If individuals decide on their location in part due to the proximity of "nice" places, we would expect those metropolitan areas further from their closest "nice" place to require a positive compensating wage differential. To test this, we rewrite equation (5) as:

$$
L N_{-} R W A G E_{i}=\alpha+\beta_{1} X_{i}+\beta_{2} \Gamma_{j}+\beta_{3} \Theta_{j}+\varepsilon_{i}
$$

where $\Theta_{j}$ is a measure of driving distance in miles to the nearest "nice" place. ${ }^{14}$ The actual driving time for a given distance may vary significantly across MSAs. However, our inclusion of population density and average commuting time in the regressions will help to control for this. The estimate of $\beta_{3}$ is expected to be positive. Results from the

${ }^{14}$ Driving distances in miles are generated from Mapquest (www.mapquest.com). 
MSA-level variables from this regression on the pooled sample are presented in Column 1 of Table 3. The estimated coefficients on the individual-level variables change very little, so we do not report these in Table 3.

The estimated coefficient on our variable of interest, distance to the nearest "nice" place, is 0.00034 , and is statistically significant at the five-percent level. This coefficient is of the expected sign, and is sizeable, suggesting that individuals would be willing to take a 3.4 percent pay cut in order to have the closest "nice" place one hundred miles closer. This compensating wage differential is in addition to effects due to environmental amenities within the MSA itself. The magnitude and statistical significance of some amenity variables within the metropolitan area (reported in Table 2) fall slightly when amenities outside the metropolitan area are included. This suggests that the effects of MSA-level amenities previously estimated may in part proxy for "nice" places outside of the metropolitan area boundaries.

Results broken out by gender can be found in Columns 2 and 3. The patterns are similar to those found in the pooled regression. As in Table 2, climate is significant only for men. The percent of land that is state recreation area now becomes significant at the ten-percent level for women. The point estimate of the distance coefficient for men is statistically significant at the one-percent level, and at 0.00043 is larger in magnitude than the coefficent estimated from the pooled sample. There is no evidence that distance to the nearest "nice" place affects the wages of women. ${ }^{15}$

\footnotetext{
15 The smaller coefficient on the distance variable for women could be due to joint decision-making within the household over location. When regressions for women are run only on those women who were heads of household, the coefficient becomes larger in magnitude, and the standard error becomes smaller. However, the distance variable is still not statistically significant at conventional confidence levels.
} 
In Table 4, we use the coefficient on distance in the pooled regression from Table 3 to illustrate the effect of proximity to "nice" places on real wages. This table presents the 20 MSAs with the highest and lowest compensating wage differentials due to distance to nearest nice place (i.e., the 20 MSAs closest to and farthest away from their nearest "nice" place). The contribution of distance to wages is calculated by multiplying the codfficient on distance in the pooled regression by the driving distance in miles. For Tucson, Arizona, the MSA with the closest "nice" place, this value is 0.0033 . The contribution of distance to wages for Omaha, NE, the MSA furthest from its nearest "nice" place, is 0.1537 . This implies that if Omaha and Tucson were otherwise identical, a 15 percent wage premium would be required for an individual to choose to live in Omaha instead of Tucson. Another way of putting this is that if you moved Tucson to the latitude and longitude of Omaha, retaining all of Tucson's characteristics, Tucson residents would on average require a 15 percent compensating differential for making the move.

It is important to remember that these distance effects are in addition to the effects of natural amenities within the MSAs themselves. Table 5 ranks MSAs by their level of natural amenities and disamenities (climate, topographical variation, surface water area, percent of MSA that is state recreation land, air quality, superfund sites), weighted by the implicit price for these amenities resulting from the pooled regression in Table 3 . The first column shows the rankings without including distance to the nearest "nice" place. Column 2 adds the effect of this variable and shows how the rankings change. As would be expected from Table 3, adding distance improves the ranking of Tucson, from $13^{\text {th }}$ to 
$9^{\text {th }}$. Las Vegas, which scores $10^{\text {th }}$ based primarily on climate, drops to $19^{\text {th }}$ when the distance variable is added.

However, notwithstanding cases like Tucson and Las Vegas, the ordering of the top 25 MSAs is remarkably similar both with and without the distance effect. This is most likely due to the fact that those MSAs that are near "nice" places are likely to be "nice" places themselves. More striking effects can be seen once we move out of the top 25. Adding distance moves the ranking of Knoxville, Tennessee (close to Great Smoky Mountains National Park) up from 41 to 30, and of Little Rock, Arkansas (close to Hot Springs National Park) up from 54 to 38. Conversely, adding distance significantly reduces the rankings of places like Rochester, NY (from 59 to 78), Fort Worth (from 65 to 87 ), and Omaha (from 75 to 90$).{ }^{16}$

The results in Table 3 suggest that distance to the nearest "nice" place is an amenity that has a sizeable associated compensating wage differential. However, it is possible that the relationship between distance and log real wages is nonlinear. To check for this possibility, we estimate models that allows for such a nonlinear relationship. Specifically, we run a regression that allows distance to take the form of a quadratic, and a regression that allows distance to take the form of a cubic polynomial. In neither case were the estimated coefficients on the higher order terms significantly different from zero, suggesting that a linear specification is a better fit for the data. ${ }^{17}$

Finally, by restricting our sample to full time workers, we may be missing differences in hours that are correlated with accessibility to "nice" places. Specifically, if access to these places is complementary with leisure, individuals in MSAs that are more

\footnotetext{
${ }^{16}$ These MSAs are not reported in Table 5. A full set of rankings is available from the authors.

${ }^{17}$ Results from these regressions are available from the authors.
} 
accessible may choose to work fewer hours. To test whether this is happening, we regress log hours worked on the same set of independent variables for those individuals in the CPS who report positive hours. These results are presented in Table 6 .

The first two columns show that for the pooled sample and for men, there is no significant effect of distance on hours worked. However, column 3, which presents results for women, does show evidence of responsiveness along the hours margin. Women who live closer to the nearest "nice" place are likely to work fewer hours, with an effect that is statistically significant at the one-percent level. The magnitude of the estimated coefficient suggests that having the nearest "nice" place 100 miles closer is associated with a reduction in hours of $1.2 \%$.

\section{$\underline{\text { Conclusion }}$}

The results presented above provide evidence that individuals are willing to accept lower wages to live in close proximity to "nice" places. Our results have two broad sets of implications, one for the literature on residential location and the valuation of amenities, the other for public policy.

The main implication for the literature on residential location is that the attributes of any location include its proximities with respect to other places. When the other sites are places of work or of trade, standard theory generates patterns of wages and rents that depend on location. The logic of location theory can and should be extended to situations where the proximal sites provide recreational or other natural resource amenities. People who like rafting trips, but whose economic opportunities are much greater in urban areas than near canyons, will have a willingness to pay to live in urban areas that are in closer 
proximity to good rafting water. This paper is a first step in showing that such effects may be quantitatively important. Given this importance, the travel cost method of valuing access to recreational sites, which takes residential location as given, will generally underestimate the value of such proximity. We are confident that in a wellspecified location model, consumers' residential locations will not be random with respect to distant (but not too distant) recreational opportunities.

The results in this paper suggest that natural resource amenities (and amenities in general) that are at some remove from metropolitan areas can be converted into production amenities via reductions in the real wage in the affected metropolitan area. Depending on the organization of markets and the distribution of tastes, the benefits from such amenities will accrue in part to consumers, in part to landlords, and in part to the customers and stockholders of firms that produce in the affected urban areas. There may also be consequences for local and regional economic growth. The important point is that real economic benefits may be realized at considerable economic remove from the location of the amenities themselves. Local development agencies may be able to enact policies that internalize the effects of amenities within their jurisdiction. However, it is unlikely that these agencies or the citizens they represent can do so for those "nice" places which are not within their jurisdiction.

Federal policies towards the national parks and national seashores that we use to measure "nice" places in this paper may indeed take into account the effects on metropolitan areas within a few hours drive. But as a general matter, neither governmental nor private structures will exist that allow the firms and residents of metropolitan areas to articulate their willingness to pay for amenities in "nice" places that 
are at some remove. We hope that further work on this set of issues will allow us, and policymakers, to calibrate the relevant willingness to pay, and to identify the value of natural resource amenities to the economic activity and welfare realized in nearby urban areas. 


\section{REFERENCES}

Beeson, Patricia E. 1991. "Amenities and Regional Differences in Returns to Worker Characteristics." Journal of Urban Economics, 30: 224-241.

Bouquets, Glenn C., Mark C. Berger, John P. Hoehn. 1988. "New Estimates of Quality of Life in Urban Areas." American Economic Review, 78(1): 89-107.

Bowes, M. and J. Krutilla. 1989. Multiple Use Management: The Economics of Public Forestlands. Washington, D.C.: Resources for the Future.

Courant, Paul N. and Alan V. Deardorff. 1993. "Amenities, Nontraded Goods, and the Trade of Lumpy Countries." Journal of Urban Economics, 34(2): 299-317.

Courant, Paul, Ernie Niemi, and W. Edward Whitelaw. 1997. "An Analytic Typology for Examining the Economic Effects of Ecosystem Management." Unpublished Manuscript.

Fletcher, J., W. Adamowicz, and T. Graham-Tomasi. 1990. "The Travel Cost Model of Recreation Demand." Leisure Sciences, 12: 119-47.

Ginther, Donna K. and Madeline Zavodny. 2001. "Is the Male Marriage Premium Due to Selection? The Effect of Shotgun Weddings on the Return to Marriage." Journal of Population Economics 14(2): 313-28.

Gray, Jeffrey S. 1997. “The Fall in Men's Return to Marriage.” Journal of Human Resources 32:481-504.

Greenwood, Michael J., Gary L. Hunt, Dan S. Rickman, and George I. Treyz. 1991. "Migration, Regional Equilibrium, and the Estimation of Compensating Differentials." American Economic Review 81 (5): 1382-1390.

Gyourko, Joseph, Matthew Kahn, and Joseph Tracy. 1999. "Quality of Life and Environmental Comparisons." In Handbook of Regional and Urban Economics, eds. Edwin S. Mills and Paul Cheshire. Elsevier Press: 1413-1454.

Gyourko, Joseph, and Joseph Tracy. 1991. "The Structure of Local Public Finance and the Quality of Life." Journal of Political Economy 99:774-806.

Hausman, J.A. 1978. "Specification Tests in Econometrics." Econometrica 46: 125171.

Korenman, Sanders and David Neumark. 1992. "Marriage, Motherhood, and Wages." Journal of Human Resources 27:233-55. 
Lerner, S. and W. Poole. 1999. The Economic Benefits of Parks and Open Space: How Land Conservation Helps Communities Grow Smart and Protect the Bottom Line. The Trust for Public Land.

McGranahan, David. 1999. "Natural Amenities Drive Rural Population Change." USDA ERS Agricultural Economic Report \#781.

Moulton, Brent R. 1986. "Random Group Effects and the Precision of Regression Estimates." Journal of Econometrics 32: 385-397.

Niemi, Ernie, Ed Whitelaw, and Andrew Johnston. 1999. "The Sky did NOT Fall: The Pacific Northwest's Response to Logging Reductions. Eugene, Oregon: ECONorthwest.

Power, Thomas Michael. 1996. “The Wealth Of Nature: Environmental Quality, Not Mining, Logging, Or Ranching, Is Driving Local Economic Development In The West." Issues in Science and Technology 12(3): 48.

Roback, Jennifer. 1982. "Wages, Rents, and Quality of Life." Journal of Political Economy 90(6): 1257-1278.

Roback, Jennifer. 1988. "Wages, Rents and Amenities: Differences among Workers and Regions." Economic Inquiry 26 (1): 23-41.

Rosen, Sherwin. 1979. "Wage-Based Indexes of Urban Quality of Life.” In Current Issues in Urban Economics, Peter Mieszkowski and Malcom Straszheim, Eds. Baltimore: Johns Hopkins University Press, 74-104.

Rudzitis, G. and R. Johnson. 2000. "The Impact of Wilderness and Other Wildlands on Local Economies and Regional Development Trends." In Wilderness Science in a Time of Change Conference-- Volume 2: Wilderness Within the Context of Larger Systems. U.S. Department of Agriculture, Forest Service, Rocky Mountain Research Station.

Savageau, David and Geoffrey Loftus. 1997. Places Rated Almanac, Fifth Edition. Hungry Minds, Inc.

Smith, V. Kerry and Ju Chin Huang. 1995. "Can Markets Value Air Quality? A Metaanalysis of Hedonic Property Value Models." Journal of Political Economy 103(1): 209-27.

U.S. Department of Commerce, Bureau of the Census. 1994. County and City Data Book. Washington, D.C.: General Printing Office. 
Table 1: Summary Statistics

\begin{tabular}{|c|c|c|c|}
\hline Variable Name & Pooled Sample & Men & Women \\
\hline \multicolumn{4}{|l|}{ Individual Level Variables } \\
\hline Log real wage & 6.038 & 6.170 & 5.865 \\
\hline & $(0.735)$ & $(0.742)$ & $(0.689)$ \\
\hline Age & 39.060 & 39.155 & 38.935 \\
\hline & (11.387) & (11.415) & $(11.350)$ \\
\hline White & 0.808 & 0.829 & 0.780 \\
\hline Married & 0.602 & 0.657 & 0.530 \\
\hline Household head & 0.818 & 0.816 & 0.821 \\
\hline Veteran & 0.120 & 0.203 & 0.012 \\
\hline Union member & 0.039 & 0.044 & 0.033 \\
\hline High school graduate & 0.305 & 0.294 & 0.319 \\
\hline Some college & 0.268 & 0.250 & 0.291 \\
\hline College graduate & 0.310 & 0.321 & 0.297 \\
\hline Children under 18 & 0.419 & 0.433 & 0.401 \\
\hline \multicolumn{4}{|l|}{ MSA Level Variables } \\
\hline Surface water area & $\begin{array}{c}0.749 \\
(0.790)\end{array}$ & $\begin{array}{c}0.751 \\
(0.793)\end{array}$ & $\begin{array}{c}0.746 \\
(0.786)\end{array}$ \\
\hline Percent state recreation area & $\begin{array}{c}0.019 \\
(0.027)\end{array}$ & $\begin{array}{c}0.019 \\
(0.028)\end{array}$ & $\begin{array}{c}0.018 \\
(0.027)\end{array}$ \\
\hline $\begin{array}{l}\text { Days with unhealthy air quality } \\
\text { index }\end{array}$ & $\begin{array}{l}22.948 \\
(35.253)\end{array}$ & $\begin{array}{l}23.580 \\
(36.154)\end{array}$ & $\begin{array}{r}22.119 \\
(34.020)\end{array}$ \\
\hline Maximum topography index & $\begin{array}{l}0.493 \\
(1.003)\end{array}$ & $\begin{array}{l}0.510 \\
(1.004)\end{array}$ & $\begin{array}{c}0.472 \\
(1.001)\end{array}$ \\
\hline Average climate index & $\begin{array}{c}0.214 \\
(0.697)\end{array}$ & $\begin{array}{c}0.228 \\
(0.705)\end{array}$ & $\begin{array}{c}0.196 \\
(0.685)\end{array}$ \\
\hline Commuting time & $\begin{array}{c}32.249 \\
(45.591)\end{array}$ & $\begin{array}{c}32.515 \\
(46.252)\end{array}$ & $\begin{array}{c}31.900 \\
(44.708)\end{array}$ \\
\hline $\begin{array}{l}\text { Percent of population below } \\
\text { poverty }\end{array}$ & $\begin{array}{l}18.686 \\
(6.139)\end{array}$ & $\begin{array}{l}18.609 \\
(6.165)\end{array}$ & $\begin{array}{l}18.787 \\
(6.104)\end{array}$ \\
\hline Health care index & $\begin{array}{c}78.090 \\
(23.236)\end{array}$ & $\begin{array}{c}77.968 \\
(23.391)\end{array}$ & $\begin{array}{l}78.251 \\
(23.032)\end{array}$ \\
\hline $\begin{array}{l}\text { Driving distance to nearest "nice" } \\
\text { place }\end{array}$ & $\begin{array}{l}130.616 \\
(82.665)\end{array}$ & $\begin{array}{l}130.201 \\
(82.063)\end{array}$ & $\begin{array}{l}131.160 \\
(83.448)\end{array}$ \\
\hline Number of observations & 28,282 & 16,048 & 12,234 \\
\hline
\end{tabular}


Table 2

Effects of MSA-level Amenities on Log Real Wages

\begin{tabular}{|c|c|c|c|c|c|c|}
\hline \multirow[b]{2}{*}{ Male } & \multicolumn{2}{|c|}{ Pooled } & \multicolumn{2}{|l|}{ Men } & \multicolumn{2}{|c|}{ Women } \\
\hline & $\begin{array}{c}0.271 \\
(0.011)\end{array}$ & $* * *$ & -- & & -- & \\
\hline Age & $\begin{array}{c}0.064 \\
(0.002)\end{array}$ & $* * *$ & $\begin{array}{c}0.066 \\
(0.003)\end{array}$ & $* * *$ & $\begin{array}{c}0.065 \\
(0.004)\end{array}$ & $* * *$ \\
\hline Age squared & $\begin{array}{c}-0.0007 \\
(0.00003)\end{array}$ & $* * *$ & $\begin{array}{l}-0.0007 \\
(0.00004)\end{array}$ & $* * *$ & $\begin{array}{c}-0.0007 \\
(0.00005)\end{array}$ & $* * *$ \\
\hline White & $\begin{array}{c}0.155 \\
(0.012)\end{array}$ & $* * *$ & $\begin{array}{c}0.187 \\
(0.019)\end{array}$ & $* * *$ & $\begin{array}{c}0.119 \\
(0.011)\end{array}$ & $* * *$ \\
\hline Married & $\begin{array}{c}0.077 \\
(0.009)\end{array}$ & $* * *$ & $\begin{array}{c}0.128 \\
(0.013)\end{array}$ & $* * *$ & $\begin{array}{c}0.012 \\
(0.012)\end{array}$ & \\
\hline Household head & $\begin{array}{c}0.220 \\
(0.012)\end{array}$ & $* * *$ & $\begin{array}{c}0.223 \\
(0.014)\end{array}$ & $* * *$ & $\begin{array}{c}0.210 \\
(0.019)\end{array}$ & $* * *$ \\
\hline Veteran & $\begin{array}{c}0.040 \\
(0.012)\end{array}$ & $* * *$ & $\begin{array}{c}0.018 \\
(0.012)\end{array}$ & & $\begin{array}{r}-0.040 \\
(0.046)\end{array}$ & \\
\hline Union member & $\begin{array}{c}0.061 \\
(0.018)\end{array}$ & $* * *$ & $\begin{array}{c}0.044 \\
(0.023)\end{array}$ & $*$ & $\begin{array}{c}0.080 \\
(0.022)\end{array}$ & $* * *$ \\
\hline High school graduate & $\begin{array}{c}0.322 \\
(0.017)\end{array}$ & $* * *$ & $\begin{array}{c}0.321 \\
(0.019)\end{array}$ & $* * *$ & $\begin{array}{c}0.332 \\
(0.023)\end{array}$ & $* * *$ \\
\hline Some college & $\begin{array}{c}0.477 \\
(0.019)\end{array}$ & $* * *$ & $\begin{array}{c}0.454 \\
(0.021)\end{array}$ & $* * *$ & $\begin{array}{c}0.498 \\
(0.027)\end{array}$ & $* * *$ \\
\hline College graduate & $\begin{array}{c}0.835 \\
(0.021)\end{array}$ & $* * *$ & $\begin{array}{c}0.801 \\
(0.023)\end{array}$ & $* * *$ & $\begin{array}{c}0.859 \\
(0.028)\end{array}$ & $* * *$ \\
\hline Children under 18 & $\begin{array}{c}0.010 \\
(0.008)\end{array}$ & & $\begin{array}{c}0.040 \\
(0.010)\end{array}$ & $* * *$ & $\begin{array}{l}-0.059 \\
(0.010)\end{array}$ & $* * *$ \\
\hline Surface water area & $\begin{array}{l}-0.001 \\
(0.025)\end{array}$ & & $\begin{array}{l}0.0017 \\
(0.025)\end{array}$ & & $\begin{array}{l}-0.005 \\
(0.025)\end{array}$ & \\
\hline $\begin{array}{l}\text { Percent state } \\
\text { recreation area }\end{array}$ & $\begin{array}{l}-1.435 \\
(1.055)\end{array}$ & & $\begin{array}{l}-1.288 \\
(1.094)\end{array}$ & & $\begin{array}{l}-1.629 \\
(1.005)\end{array}$ & \\
\hline $\begin{array}{l}\text { Superfund sites per } \\
\text { capita } * 100\end{array}$ & $\begin{array}{l}0.313 \\
(7.49)\end{array}$ & & $\begin{array}{l}-0.930 \\
(7.358)\end{array}$ & & $\begin{array}{l}2.518 \\
(8.210)\end{array}$ & \\
\hline $\begin{array}{l}\text { Days with unhealthy } \\
\text { air quality index }\end{array}$ & $\begin{array}{c}0.0002 \\
(0.0005)\end{array}$ & & $\begin{array}{c}0.0002 \\
(0.0006)\end{array}$ & & $\begin{array}{c}0.0003 \\
(0.0006)\end{array}$ & \\
\hline $\begin{array}{l}\text { Maximum topography } \\
\text { index }\end{array}$ & $\begin{array}{l}-0.015 \\
(0.017)\end{array}$ & & $\begin{array}{l}-0.021 \\
(0.019)\end{array}$ & & $\begin{array}{l}-0.007 \\
(0.018)\end{array}$ & \\
\hline Average climate index & $\begin{array}{l}-0.069 \\
(0.033)\end{array}$ & ** & $\begin{array}{l}-0.096 \\
(0.037)\end{array}$ & $* *$ & $\begin{array}{l}-0.034 \\
(0.032)\end{array}$ & \\
\hline Population density & $\begin{array}{l}-0.00007 \\
(0.00001)\end{array}$ & $* * *$ & $\begin{array}{l}-0.00008 \\
(0.00002)\end{array}$ & $* * *$ & $\begin{array}{l}-0.00006 \\
(0.00001)\end{array}$ & \\
\hline Commuting time & $\begin{array}{l}0.00002 \\
(0.0003)\end{array}$ & & $\begin{array}{c}0.0001 \\
(0.0004)\end{array}$ & & $\begin{array}{l}-0.00007 \\
(0.0004)\end{array}$ & \\
\hline $\begin{array}{l}\text { Percent of population } \\
\text { below poverty }\end{array}$ & $\begin{array}{l}0.005 \\
(0.004)\end{array}$ & & $\begin{array}{c}0.004 \\
(0.004)\end{array}$ & & $\begin{array}{l}0.005 \\
(0.004)\end{array}$ & \\
\hline Health care index & $\begin{array}{l}-0.002 \\
(0.001)\end{array}$ & $* * *$ & $\begin{array}{l}-0.002 \\
(0.001)\end{array}$ & $* *$ & $\begin{array}{c}-0.002 \\
(0.001)\end{array}$ & $* * *$ \\
\hline
\end{tabular}

Notes: Also included in regressions are indicator variables for the region of residence (Northeast, West, and South, with Midwest as omitted category), city size, and the industry in which the individual works. 
Robust standard errors are in parentheses. Levels of statistical significance: *** denotes significant at the one-percent level, ** at the five-percent level, and * at the ten-percent level. 
Table 3

Effects of Nearby “Nice” Places on Log Real Wages

\begin{tabular}{|c|c|c|c|c|c|c|}
\hline & Pooled & & Men & & Women & \\
\hline $\begin{array}{l}\text { Driving distance to } \\
\text { nearest "nice" place }\end{array}$ & $\begin{array}{c}0.00034 \\
(0.00014)\end{array}$ & $* *$ & $\begin{array}{c}0.00043 \\
(0.00015)\end{array}$ & $* * *$ & $\begin{array}{c}0.00024 \\
(0.00015)\end{array}$ & \\
\hline Surface water area & $\begin{array}{l}-0.0006 \\
(0.0244)\end{array}$ & & $\begin{array}{c}0.002 \\
(0.025)\end{array}$ & & $\begin{array}{l}-0.005 \\
(0.025)\end{array}$ & \\
\hline $\begin{array}{l}\text { Percent state } \\
\text { recreation area }\end{array}$ & $\begin{array}{l}-1.439 \\
(0.954)\end{array}$ & & $\begin{array}{l}-1.306 \\
(0.972)\end{array}$ & & $\begin{array}{l}-1.622 \\
(0.929)\end{array}$ & $*$ \\
\hline $\begin{array}{l}\text { Superfund sites per } \\
\text { capita } * 100\end{array}$ & $\begin{array}{c}0.919 \\
(7.314)\end{array}$ & & $\begin{array}{l}-0.205 \\
(7.143)\end{array}$ & & $\begin{array}{c}2.988 \\
(8.065)\end{array}$ & \\
\hline $\begin{array}{l}\text { Days with unhealthy } \\
\text { air quality index }\end{array}$ & $\begin{array}{c}0.0002 \\
(0.0005)\end{array}$ & & $\begin{array}{c}0.0002 \\
(0.0005)\end{array}$ & & $\begin{array}{c}0.0003 \\
(0.0006)\end{array}$ & \\
\hline $\begin{array}{l}\text { Maximum topography } \\
\text { index }\end{array}$ & $\begin{array}{l}-0.020 \\
(0.017)\end{array}$ & & $\begin{array}{l}-0.027 \\
(0.018)\end{array}$ & & $\begin{array}{l}-0.010 \\
(0.017)\end{array}$ & \\
\hline Average climate index & $\begin{array}{l}-0.059 \\
(0.031)\end{array}$ & $*$ & $\begin{array}{l}-0.082 \\
(0.035)\end{array}$ & $* *$ & $\begin{array}{l}-0.027 \\
(0.030)\end{array}$ & \\
\hline Population density & $\begin{array}{l}-0.00006 \\
(0.00001)\end{array}$ & $* * *$ & $\begin{array}{l}-0.00007 \\
(0.00001)\end{array}$ & $* * *$ & $\begin{array}{l}-0.00006 \\
(0.00001)\end{array}$ & $* * *$ \\
\hline Commuting time & $\begin{array}{l}-0.00004 \\
(0.00036)\end{array}$ & & $\begin{array}{c}0.00004 \\
(0.00035)\end{array}$ & & $\begin{array}{l}-0.0001 \\
(0.0004)\end{array}$ & \\
\hline $\begin{array}{l}\text { Percent of population } \\
\text { below poverty }\end{array}$ & $\begin{array}{c}0.005 \\
(0.004)\end{array}$ & & $\begin{array}{c}0.004 \\
(0.004)\end{array}$ & & $\begin{array}{c}0.005 \\
(0.004)\end{array}$ & \\
\hline Health care index & $\begin{array}{l}-0.002 \\
(0.001)\end{array}$ & $* * *$ & $\begin{array}{l}-0.002 \\
(0.001)\end{array}$ & $* *$ & $\begin{array}{l}-0.002 \\
(0.001)\end{array}$ & $* * *$ \\
\hline
\end{tabular}

Notes: These regressions include all of the individual-level characteristics found in Table 2. Also included in regressions are indicator variables for the region of residence (Northeast, West, and South, with Midwest as omitted category), city size, and the industry in which the individual works. Robust standard errors a re in parentheses. Levels of statistical significance: $* * *$ denotes significant at the one-percent level, $* *$ at the five-percent level, and $*$ at the ten-percent level. 
Table 4

Rankings of MSAs by Wage Effects Due to Distance Variables

\begin{tabular}{lrll}
\hline \multicolumn{1}{c}{ Top 20 } & $\begin{array}{r}\text { Wage } \\
\text { Effect }\end{array}$ & \multicolumn{1}{c}{ Bottom 20 } & $\begin{array}{c}\text { Wage } \\
\text { Effect }\end{array}$ \\
\hline & & & \\
Tucson, AZ & 0.0033 & Buffalo-Niagara Falls, NY & 0.0692 \\
Oxnard-Ventura, CA & 0.0049 & New Orleans, LA & 0.0705 \\
Cleveland-Lorain-Elyria, OH & 0.0055 & Charleston-No. Charleston, SC & 0.0711 \\
Akron, OH & 0.0089 & Charlotte-Gastonia-Rock Hill, NC & 0.0723 \\
Nassau-Suffolk, NY & 0.0090 & Minneapolis-St Paul, MN & 0.0769 \\
Miami, FL & 0.0102 & Austin-San Marcos, TX & 0.0776 \\
Jacksonville, FL & 0.0125 & Houston, TX & 0.0785 \\
Orlando, FL & & Greensboro-Winston-Salem-High & \\
& 0.0135 & Point, NC & 0.0815 \\
Knoxville, TN & 0.0149 & Albuquerque, NM & 0.0847 \\
San Francisco, CA & 0.0151 & Tulsa, OK & 0.0867 \\
Chicago, IL & 0.0157 & Birmingham, AL & 0.0884 \\
Oakland, CA & 0.0163 & Baton Rouge, LA & 0.0895 \\
Little Rock-North Little Rock, & & Rochester, NY & \\
$\quad$ AR & 0.0184 & & 0.0910 \\
Ft. Lauderdale, FL & 0.0196 & Dallas, TX & 0.0992 \\
Youngstown-Warren, OH & 0.0202 & St Louis, MO & 0.1004 \\
New York, NY & 0.0206 & Syracuse, NY & 0.1036 \\
Bergen-Passaic, NJ & 0.0219 & Oklahoma City, OK & 0.1085 \\
Jersey City, NJ & 0.0223 & Ft Worth-Arlington, TX & 0.1101 \\
Los Angeles-Long Beach, CA & 0.0241 & Kansas City, KS-MO & 0.1424 \\
Newark, NJ & 0.0244 & Omaha, NE & 0.1537 \\
& & & \\
\hline
\end{tabular}


Table 5

\section{Rankings of Metropolitan Areas by Natural Amenities}

\begin{tabular}{cll}
\hline & & Sorted by: \\
\hline & Natural Amenities & Natural Amenities plus Distance to Nearest \\
\cline { 2 - 3 } 1 & San Diego, CA & San Diego, CA (1) \\
2 & San Francisco, CA & San Francisco, CA (2) \\
3 & San Jose, CA & Oxnard-Ventura, CA (4) \\
4 & Oxnard-Ventura, CA & San Jose, CA (3) \\
5 & El Paso, TX & Oakland, CA (6) \\
6 & Oakland, CA & Los Angeles, CA (8) \\
7 & Anaheim-Santa Ana, CA & Anaheim-Santa Ana, CA (7) \\
8 & Los Angeles, CA & El Paso, TX (5) \\
9 & Sacramento, CA & Tucson, AZ (13) \\
10 & Las Vegas, NV & Sacramento, CA (9) \\
11 & Denver, CO & Orlando, FL (16) \\
12 & Salt Lake City, UT & Denver, CO (11) \\
13 & Tucson, AZ & New York, NY (14) \\
14 & New York, NY & Fresno, CA (17) \\
15 & Phoenix-Mesa, AZ & Newark, NJ (18) \\
16 & Orlando, FL & Seattle-Bellevue-Everett, WA (19) \\
17 & Fresno, CA & Bergen-Passaic, NJ (18) \\
18 & Newark, NJ & Phoenix-Mesa, AZ (15) \\
19 & Seattle-Bellevue-Everett, WA & Las Vegas, NV (10) \\
20 & Bergen-Passaic, NJ & Miami, FL (27) \\
21 & Albuquerque, NM & Bakersfield, CA (23) \\
22 & Portland-Vancouver, OR-WA & Nassau-Suffolk, NY (35) \\
23 & Bakersfield, CA & Ft Lauderdale, FL (29) \\
24 & Greenville, SC & Riverside-San Bernardino, CA (25) \\
25 & Riverside-San Bernadino, CA & Portland-Vancouver, OR-WA (22) \\
& & \\
\hline
\end{tabular}


Table 6

Effects of Nearby “Nice” Places on Log Hours Worked

\begin{tabular}{|c|c|c|c|c|c|c|}
\hline & Pooled & & Men & & Women & \\
\hline $\begin{array}{l}\text { Driving distance to } \\
\text { nearest "nice" place }\end{array}$ & $\begin{array}{c}\mathbf{0 . 0 0 0 0 2} \\
(\mathbf{0 . 0 0 0 0 3})\end{array}$ & & $\begin{array}{r}-0.00006 \\
(0.00004)\end{array}$ & & $\begin{array}{c}0.00012 \\
(0.00004)\end{array}$ & $* * *$ \\
\hline Surface water area & $\begin{array}{l}-0.00789 \\
(0.00344)\end{array}$ & & $\begin{array}{l}-0.00841 \\
(0.00363)\end{array}$ & $* *$ & $\begin{array}{l}-0.00797 \\
(0.00477)\end{array}$ & $*$ \\
\hline $\begin{array}{l}\text { Percent state } \\
\text { recreation area }\end{array}$ & $\begin{array}{l}-0.09899 \\
(0.06551)\end{array}$ & & $\begin{array}{l}-0.03050 \\
(0.06402)\end{array}$ & & $\begin{array}{l}-0.17692 \\
(0.08049)\end{array}$ & $* *$ \\
\hline $\begin{array}{l}\text { Superfund sites per } \\
\text { capita } * 100\end{array}$ & $\begin{array}{l}1.33421 \\
(0.88129)\end{array}$ & & $\begin{array}{l}1.03712 \\
(0.96386)\end{array}$ & & $\begin{array}{l}1.7929 \\
(1.3153)\end{array}$ & \\
\hline $\begin{array}{l}\text { Days with unhealthy } \\
\text { air quality index }\end{array}$ & $\begin{array}{l}-0.00010 \\
(0.00008)\end{array}$ & & $\begin{array}{c}0.00002 \\
(0.00008)\end{array}$ & & $\begin{array}{l}-0.00023 \\
(0.00014)\end{array}$ & \\
\hline $\begin{array}{l}\text { Maximum topography } \\
\text { index }\end{array}$ & $\begin{array}{c}0.00162 \\
(0.00362)\end{array}$ & & $\begin{array}{l}-0.00143 \\
(0.00364)\end{array}$ & & $\begin{array}{c}0.00401 \\
(0.00599)\end{array}$ & \\
\hline Average climate index & $\begin{array}{c}0.01551 \\
(0.00549)\end{array}$ & $* * *$ & $\begin{array}{l}-0.00908 \\
(0.00593)\end{array}$ & & $\begin{array}{c}0.03836 \\
(0.00885)\end{array}$ & $* * *$ \\
\hline Population density & $\begin{array}{c}6.43 \times 10^{-6} \\
\left(1.51 \times 10^{-6}\right)\end{array}$ & $* * *$ & $\begin{array}{c}3.96 \times 10^{-7} \\
\left(2.03 \times 10^{-6}\right)\end{array}$ & & $\begin{array}{c}0.00001 \\
\left(2.08 \times 10^{-6}\right)\end{array}$ & $* * *$ \\
\hline Commuting time & $\begin{array}{l}-0.00003 \\
(0.00004)\end{array}$ & & $\begin{array}{l}-0.00003 \\
(0.00005)\end{array}$ & & $\begin{array}{l}-0.00002 \\
(0.00006)\end{array}$ & \\
\hline $\begin{array}{l}\text { Percent of population } \\
\text { below poverty } \\
\text { Health care index }\end{array}$ & $\begin{array}{l}-0.00076 \\
(0.00038) \\
-0.00008 \\
(0.00015)\end{array}$ & $*$ & $\begin{array}{l}-0.00039 \\
(0.00050) \\
-0.00018 \\
(0.00015)\end{array}$ & & $\begin{array}{l}-0.00101 \\
(0.00050) \\
1.93 \times 10^{-6} \\
(0.00020)\end{array}$ & $* *$ \\
\hline
\end{tabular}

Notes: Dependent variable is log hours worked. The sample includes those individuals who reported positive hours. These regressions include all of the individual-level characteristics found in Table 2. Also included in regressions are indicator variables for the region of residence (Northeast, West, and South, with Midwest as omitted category), city size, and the industry in which the individual works. Robust standard errors are in parentheses. Levels of statistical significance: $* * *$ denotes significant at the one-percent level, $* *$ at the five-percent level, and * at the ten-percent level. 


\section{Appendix A: List of SMSAs Used in Analysis}

Akron, $\mathrm{OH}$

Albany-Schenectady-Troy, NY

Albuquerque, NM

Allentown-Bethlehem-Easton, PA

Anaheim-Santa Ana, CA

Atlanta, GA

Austin-San Marcos, TX

Bakersfield, CA

Baltimore, MD

Baton Rouge, LA

Bergen-Passaic, NJ

Birmingham, AL

Boston, MA-NH

Buffalo-Niagara Falls, NY

Charleston-No Charleston, SC

Charlotte-Gastonia-Rock Hill, NC-SC

Chicago, IL

Cincinnati, OH-KY-IN

Cleveland-Lorain-Elyria, $\mathrm{OH}$

Columbus, $\mathrm{OH}$

Dallas, TX

Dayton-Springfield, $\mathrm{OH}$

Denver, CO

Detroit, MI

El Paso, TX

Fort Lauderdale, FL

Fort Worth-Arlington, TX

Fresno, CA

Grand Rapids-Muskegon-Holland, MI

Greensboro-Winston Salem-High Point, NC

Greenville-Spartanburg-Anderson, SC

Harrisburg-Lebanon-Carlisle, PA

Hartford, CT

Houston, TX

Indianapolis, IN

Jacksonville, FL

Jersey City, NJ

Kansas City, MO-KS

Knoxville, TN

Las Vegas, NV-AZ

Little Rock-North Little Rock, AR

Los Angeles-Long Beach, CA

Louisville, KY-IN

Memphis, TN-AR-MS

Miami FL
Middlesex-Somerset-Hunterdon, NJ

Milwaukee-Waukesha, WI

Minneapolis-St Paul, MN-WI

Monmouth-Ocean, NJ

Nashville, TN

Nassau-Suffolk, NY

New Haven-Meriden, CT

New Orleans, LA

New York, NY

Newark, NJ

Norfolk-VA Beach-Newport News, VA-NC

Oakland, CA

Oklahoma City, OK

Omaha, NE-IA

Orlando, FL

Oxnard-Ventura, CA

Philadelphia, PA-NJ

Phoenix-Mesa, AZ

Pittsburgh, PA

Portland-Vancouver, OR-WA

Providence-Fall River-Warwick, RI-MA

Raleigh-Durham-Chapel Hill, NC

Richmond-Petersburg, VA

Riverside-San Bernardino, CA

Rochester, NY

Sacramento, CA

St. Louis, MO-IL

Salt Lake City-Ogden, UT

San Antonio, TX

San Diego, CA

San Francisco, CA

San Jose

Scranton-Wilkes Barre-Hazelton, PA

Seattle-Bellevue-Everett, WA

Springfield, MA

Syracuse, NY

Tacoma, WA

Tampa-St Petersburg-Clearwater, FL

Toledo, $\mathrm{OH}$

Tucson, AZ

Tulsa, OK

Washington, DC-MD-VA-WV

West Palm Beach-Boca Raton, FL

Wilmington-Newark, DE-MD

Youngstown-Warren, $\mathrm{OH}$ 


\section{Appendix B: Data Sources}

\section{Individual level data:}

Wages, demographic information, and job characteristics come from the Current Population Survey Annual Demographic Supplement for 1995 (with calendar year data for 1994). We include full-time workers aged 18 and older who reside in the 90 largest Metropolitan Statistical Areas (MSAs), ranked according to 1990 census population estimates. We exclude those with zero earnings and any individuals reporting self employed income.

\section{MSA level characteristics:}

1. Cost of Living Index data for MSAs are generated by the American Chamber of Commerce Researchers Association (ACCRA). Annual values for 1996 were reported by Money Magazine (www.cnnmoney.com). Detailed information about the index can be found at www.coli.org/coli_about.html.

2. County level measures of climate, topography variation, and the percentage of surface area covered by water area come from the Economic Research Service (ERS) at the US Department of Agriculture. USDA takes the natural logarithm of water value to avoid bias from attributing Great Lakes and ocean coastline to coastal counties. We take the average of these values across the counties that make up each MSA See McGranahan (1999) for additional information.

3. MSA measures of commuting time (average travel time to work in minutes) and poverty rates come from the County and City Data Book (U.S. Department of Commerce, 1994).

4. State recreation acreage is background data collected by and published Savageau and Loftus (1997). 
5. Superfund sites per capita and days with unhealthy air quality (AQIDAYS, with an air quality index (AQI) above 100) come from the US Environmental Protection Agency

(EPA). Available online at http://www.epa.gov/oar/aqtrnd99/aqiall.pdf

6. Health care index comes from Savageau and Loftus (1997).

7. Land area, population, and population density are from the 1990 Census, released by the U.S. Census Bureau on March 14, 1996. City size variables are created from population data, where:

XLARGE: population greater than or equal to 4 million

LARGE population greater than or equal to 2 million and less than 4million

SMALL population less than 7 thousand 


\section{Appendix C: List of "Nice" Places in Continental U.S.}

National Parks (NP)

Acadia NP, Maine

Arches NP, Utah

Badlands NP, South Dakota

Big Bend NP, Texas

Biscayne NP, Florida

Black Canyon of the Gunnison NP, Colo.

Bryce Canyon NP, Utah

Canyonlands NP, Utah

Capitol Reef NP, Utah

Carlsbad Caverns NP, New Mexico

Channel Islands NP, California

Crater Lake NP, Oregon

Cuyahoga Valley NP, Ohio

Death Valley NP, California

Dry Tortugas NP, Florida

Everglades NP, Florida

Glacier NP, Montana

Grand Canyon NP, Arizona

Grand Teton NP, Wyoming

Great Basin NP, Nevada

Great Smoky Mountains NP, North Carolina

Guadalupe Mountains NP, Texas

Hot Springs NP, Arkansas

Isle Royale NP, Michigan

Joshua Tree NP, California

Lassen Volcanic NP, California

Mammoth Cave NP, Kentucky

Mesa Verde NP, Colorado

Mount Rainier NP, Washington

North Cascades NP, Washington

Olympic NP, Washington

Petrified Forest NP, Arizona

Redwood NP, California

Rocky Mountain NP, Colorado

Saguaro NP, Arizona

Sequoia and Kings Canyon NP, California

Shenandoah NP, Virginia

Theodore Roosevelt NP, North Dakota

Voyageurs NP, Minnesota

Wind Cave NP, South Dakota

Yellowstone NP, Wyoming

Yosemite NP, California

Zion NP, Utah
National Seashores (NS) \& Lakeshores (NL)

Apostle Island NL, Wisconsin

Assateague NS, Maryland

Canaveral NS, Florida

Cape Cod NS, Massachusetts

Cape Hatteras NS, North Carolina

Cape Lookout NS, North Carolina

Cumberland Island NS, Georgia

Fire Island NS, New York

Gulf Islands NS, Florida-Mississippi

Indiana Dunes NL, Indiana

Padre Island NS, Texas

Pictured Rocks NL, Michigan

Point Reyes NS, California

Sleeping Bear NL, Michigan 